\title{
In vitro regeneration and morphogenesis of somatic embryos of cassava ${ }^{1}$
}

\author{
Regeneração in vitro e morfogênese de embriões somáticos em mandioca
}

\author{
Ádila Melo Vidal ${ }^{2}$, Maria Angélica Pereira de Carvalho Costa ${ }^{2}$, Antônio da Silva Souza ${ }^{3}$, Weliton Antonio Bastos \\ de Almeida ${ }^{4}$ e Fernanda Vidigal Duarte Souza ${ }^{3 *}$
}

\begin{abstract}
In this study, the somatic embryogenesis and regeneration of Cigana Preta plants from shoot apices and immature leaves taken from plants cultivated in vitro were examined. To embryo induction the explants were cultivated in Murashige and Skoog (MS) medium supplemented with 2,4-dichlorophenoxyacetic acid (2,4-D) or 4-amino-3,5,6-trichloropicolinic acid (Picloram) at concentrations of 8.0 and $12 \mathrm{mg} \mathrm{L}^{-1}$. To development of embryos two media cultures with different concentration of BAP (D1 or D2) were evaluated. Embryos in the cotyledonary stage were incubated in germination medium containing MS salts and vitamins, $2.0 \mu \mathrm{M}$ copper sulfate, $2.4 \mathrm{~g} \mathrm{~L}^{-1}$ of Phytagel ${ }^{\circledR}$ and $1.77 \mu \mathrm{M}$ BAP. The highest frequency of calluses and the greatest number of embryos per explant were obtained using the auxin picloram at a concentration of $8.0 \mathrm{mg} \mathrm{L}^{-1}$. The plants regenerated in the picloram treatment exhibited normal development and were transferred to a multiplication medium after a minimum of four weeks. The histological sections of the malformed embryos from foliar explants cultured in the presence of 2,4-D demonstrated that the origin of the cotyledonary structures was independent of the formation of the shoot apical meristem, which was not formed in the embryos, and the majority of the embryos were classified as cornet-shaped. This study demonstrates that in cassava, the use of different auxins provides different conditions for the formation of somatic embryos, and the low rate of conversion into plants results from abnormalities in the embryos.
\end{abstract}

Key words: Cassava. Somatic embryogenesis. Regulators-plants.

RESUMO - Este trabalho teve como objetivo estudar a embriogênese somática e a regeneração de plantas da variedade Cigana Preta a partir de ápices caulinares e folhas imaturas obtidos de plantas cultivadas in vitro. Para a indução de embriões, os explantes foram cultivados em meio Murashige e Skoog (MS) suplementados com ácido 2,4 diclorofenoxiacético (2,4-D) ou 4-amino-3,5,6-trichloropicolinic acid (Picloram), ambos nas concentrações 8,0 e $12 \mathrm{mg} \mathrm{L}^{-1}$. O desenvolvimento dos embriões obtidos foi testado por dois meios de cultura com diferentes concentrações de benzilaminopurina (BAP) (D1 ou D2). Embriões em estágio cotiledonar foram incubados em meio de germinação, constituído de sais e vitaminas do MS, 2,0 $\mu \mathrm{M}$ de sulfato de cobre, 2,4 $\mathrm{g} \mathrm{L}^{-1}$ de Phytage $^{\circledR}$, e 1,77 $\mu \mathrm{M}$ BAP. A maior frequência de calos e números de embriões por explantes foi obtida com $8,0 \mathrm{mg} \mathrm{L}^{-1}$ da auxina Picloram. As plantas regeneradas, oriundas do tratamento com Picloram apresentaram desenvolvimento normal e num período mínimo de quatro semanas foram transferidas para meio de multiplicação. Cortes histológicos de embriões malformados, provenientes dos explantes foliares cultivados em 2,4-D revelaram que as estruturas cotiledonares têm origens independentes da formação do meristema apical caulinar e não houve formação do meristema apical caulinar nos embriões, sendo a maioria classificado como corneta. Este trabalho demonstrou que em mandioca o uso de diferentes auxinas proporciona diferentes condições para a formação de embriões somáticos e que a baixa conversão em plantas foi decorrente de anormalidades desses embriões.

Palavras-chave: Mandioca. Embriogênese somática. Plantas-reguladores.

\footnotetext{
*Autor para correspondência

${ }^{1}$ Recebido para publicação 24/05/2013; aprovado em 28/02/2014

Parte da Dissertação de Mestrado do primeiro autor apresentada à Universidade Federal do Recôncavo da Bahia

${ }^{2}$ Programa de Pós-Graduação em Ciências Agrárias, Centro de Ciências Agrárias, Ambientais e Biológicas, Universidade Federal do Recôncavo da Bahia, Cruz das Almas-BA, Brasil, 44.380-000, amelovidal@yahoo.com.br, mapcosta63@gmail.com

${ }^{3}$ Embrapa Mandioca e Fruticultura, Cruz das Almas-BA, Brasil, 44.380-000, antonio.silva-souza@embrapa.br, fernanda.souza@ embrapa.br

${ }^{4}$ Faculdade Maria Milza, Governador Mangabeira-BA, Brasil, 44.350-000, weliton@ famam.com.br
} 


\section{INTRODUCTION}

Cassava (Manihot esculenta Crantz) is cultivated mainly by low-income farmers for exploitation and consumption and is an important source of income and socioeconomic development in northern and northeastern areas of Brazil in particular. However, in spite of its importance, the cassava plant exhibits a number of limitations, such as low protein content, high concentrations of cyanogenic glycosides in the roots, post-harvest deterioration (ALVES et al., 2005; SILVA et al., 2011), a low multiplication rate, and poor quality of the stem cuttings used for planting.

The development of biotechnological systems for the regeneration and transformation of the cassava plant has the potential to generate improved genotypes by integrating desirable traits into the cultivars that are preferred by farmers (TAYLOR et al., 2004). Somatic embryogenesis is a highly efficient process for the regeneration and micro-propagation of several species of cassava because it allows high multiplication rates and the production of individualized embryos that develop into whole plants (IBARAKI; MURATA, 2001). However, in the literature, several studies report the formation of flawed embryos and low rates of conversion into morphologically complete plants that are equivalent to the original clone (CANHOTO; RAMA; CRUZ, 2006; TAKAMI et al., 2004).

The first studies of somatic embryogenesis in cassava were performed in the 1980s (SZABADOS; HOYOS; ROCA, 1987). The most widely used basic culture medium was Murashige and Skoog (MS) medium (MURASHIGE; SKOOG, 1962) supplemented with different concentrations of auxins, usually 2,4-dichlorophenoxyacetic acid (2,4-D) and 4-amino-3,5,6-trichloropicolinic acid (picloram) (ATEHNKENG; ADETIMIRIN; NG, 2006; IBRAHIM et al., 2008; LI et al., 2009). For the somatic embryogenesis of cassava, the source and type of the initial explant is an important factor. In addition, because the formation of embryogenic structures must be optimized for each individual cultivar and not all cultivars are prone to embryo formation, regeneration, or transformation, the efficiency of this technique is dependent on the genotypes of the cultivars (ROSSIN; REY, 2011).

The aim of several studies was to increase the efficiency of somatic embryo production and their subsequent development into plantlets; however, few studies investigated thoroughly the morphogenesis and anatomy of the generated embryos, which would provide a better understanding of the system and explain the high rates of malformed embryos (IBRAHIM et al., 2006). According to Uzelac et al. (2007) low frequency of somatic embryo maturation and germination is well known to be the limiting factor for the application of somatic embryogenesis for the improvement of a number of species. Therefore, the histological investigation of the formed structures allows for a more thorough characterization of the embryogenic processes and the potential to identify flaws in the formation of somatic embryos, which could provide the foundation for novel approaches.

The aim of this study was to assess the development of somatic embryos of cassava plants following different treatments and to perform histological analyses of the malformed embryos to establish the efficiency of this plant regeneration system.

\section{MATERIALS AND METHODS}

\section{Plant material}

Cassava plants of the Cigana Preta variety, maintained in the Cassava Germplasm Bank of Embrapa Cassava and Fruits in Cruz das Almas - BA, were previously established in vitro for subsequent use as explant source.

\section{Induction of somatic embryogenesis}

Apex shoots and immature leaves collected from plants of the Cigana Preta variety cultured in vitro were placed in Petri dishes containing $40 \mathrm{~mL}$ of MS medium supplemented with $20 \mathrm{~g} \mathrm{~L}^{-1}$ of sucrose, $0.5 \mathrm{mg} \mathrm{L}^{-1}$ of copper sulfate, and 8 and $12 \mathrm{mg} \mathrm{L}^{-1}$ of picloram (ATEHNKENG; ADETIMIRIN; NG, 2006) or 2,4-D (LI et al., 1998). The medium was solidified using $2.4 \mathrm{~g} \mathrm{~L}^{-1}$ of Phytagel ${ }^{\circledR}$, and the Petri dishes were cultured in the dark at $27^{\circ} \mathrm{C}$. Each treatment comprised five Petri dishes, each containing 12 explants ( 60 explants/treatment). After 30 days, the percentage of explants that formed calluses was assessed. The percentage of calluses containing embryos and the number of embryos per callus were assessed on days 55 and 75 .

\section{Development and germination of somatic embryos}

To produce plants, the embryogenic cultures that originated in the induction medium were transferred to Petri dishes containing one of the following media (D1 or D2): D1 contained MS salts, $20 \mathrm{~g} \mathrm{~L}^{-1}$ of sucrose, $2 \mu \mathrm{M}$ copper sulfate, $0.2 \mu \mathrm{M}$ BAP, and $2.0 \mathrm{~g} \mathrm{~L}^{-1}$ of Phytagel ${ }^{\circledR}$ (JOSEPH; YEOH; LOH, 2004), and D2 contained MS salts, $20 \mathrm{~g} \mathrm{~L}^{-1}$ of sucrose, $2 \mu \mathrm{M}$ copper sulfate, $0.44 \mu \mathrm{M}$ BAP, and $6.0 \mathrm{~g} \mathrm{~L}^{-1}$ of agarose (LI et al., 1998). The cultures were maintained in a growth room at $27 \pm 1{ }^{\circ} \mathrm{C}$ with a 16hour photoperiod and a photon flux density of $30 \mu \mathrm{mol}$ $\mathrm{m}^{-2} \mathrm{~s}^{-1}$ for two to 10 weeks. The embryos were transferred to test tubes containing the germination medium (MS salts and vitamins, $20 \mathrm{~g} \mathrm{~L}^{-1}$ of sucrose, $2 \mu \mathrm{M}$ copper sulfate, $1.77 \mu \mathrm{M}$ BAP, and solidified with $2.4 \mathrm{~g} \mathrm{~L}^{-1}$ of Phytagel $\left.^{\circledR}\right)$ and were maintained under the same incubation conditions (ZHANG et al., 2000). The embryos were 
maintained in the germination medium for at least four weeks, and when developed, the plantlets were transferred to the basic cassava multiplication medium consisting of $1 / 3$ of the MS macro and micronutrients supplemented with $0.35 \mathrm{mg} \mathrm{L}^{-1}$ of thiamine, $35 \mathrm{mg} \mathrm{L}^{-1}$ of inositol, $0.01 \mathrm{mg} \mathrm{L}^{-1}$ of naphthaleneacetic acid (NAA), $0.01 \mathrm{mg} \mathrm{L}^{-1}$ of gibberellic acid $\left(\mathrm{GA}_{3}\right), 20 \mathrm{~g} \mathrm{~L}^{-1}$ of sucrose, and $2.4 \mathrm{~g} \mathrm{~L}^{-1}$ of Phytagel ${ }^{\circledR}$ (CENTRO INTERNACIONAL DE AGRICULTURA TROPICAL, 1982).

\section{Histological analysis}

Because of the high number of malformations associated with the 2,4-D growth regulator, the histological analysis was performed exclusively on the materials from the 2,4-D treatments. However, because of the small number of embryos resulting from the foliar explants cultured in the presence of 2,4-D, the embryo samples were collected for histological analysis after development in D1 medium. The samples were fixed using a solution of (3\%) paraformaldehyde and (3\%) glutaraldehyde in sodium cacodylate buffer (0.2 M, pH 7.2). Next, the samples were dehydrated slowly by incubation in a series of solutions comprising $100 \%$ methyl cellosolve, $100 \%$ ethanol, $100 \%$ propanol, and $100 \%$ butanol pre-infiltrated in butanol: infiltration medium $(1: 1 \mathrm{v} / \mathrm{v})$, followed by immediate immersion in the infiltration medium (HistoResin) (RODRIGUEZ; WETZSTEIN, 1998). When the samples became translucent and fell to the bottom of the receptacle, they were incubated in HistoResin containing hardener for 48 hours. The histological sections ( $5 \mathrm{~mm}$ thick) were stained using $(5 \%)$ acid fuchsin followed by $(1 \%)$ toluidine blue (FEDER; O'BRIEN, 1968). After the preparation of the slides, the presence or the absence of shoot and root apices as well as their vascular connections were assessed.

\section{RESULTS AND DISCUSSION}

On day 30 after inoculation, independent of their type (i.e., shoots or leaves), $90 \%$ of the explants formed calluses (Figure 2A); however, embryos were not found at this early stage under any treatment condition. The formation of somatic embryos was detected only on day 55, and a slight increase in embryo formation was observed on day 75 . There were no significant differences relative to the type of explants and auxin concentrations in the frequency of calli with embryos at 55 or 75 days of evaluation. Statistical differences were observed only regarding to the type of auxin. The treatment with picloram favored higher frequency of calli with embryos in both evaluation periods (Figure 1).

Several reports suggest that in vitro somatic embryogenesis is induced by the introduction of a strong auxin into the culture medium. The most appropriate auxin for many species appears to be 2,4-D (JOSEPH; YEOH; LOH, 2004; MAGALHÃES et al., 2006; PINHEIRO et al., 2013), although in this study, picloram induced the formation of a greater number of embryos. A number of studies have shown that picloram is the growth regulator used most frequently to induce embryogenesis in cassava (ATEHNKENG; ADETIMIRIN; NG, 2006; ZHANG et al., 2000). Hankoua et al. (2006) demonstrated that $12 \mathrm{mg} \mathrm{L}^{-1}$ picloram induced the efficient production of somatic embryos in a number of African cassava cultivars. Atehnkeng, Adetimirin and $\mathrm{Ng}$ (2006) investigated several varieties of African cassava and obtained similar embryogenic responses using two concentrations of picloram ( 8 and $12 \mathrm{mg} \mathrm{L}^{-1}$ ). The authors selected the lowest concentration because of its lower cost. Rossin and Rey (2011) studied cultivar MT116 and produced somatic embryos when the shoot apices and the lobes from young leaves were cultivated in picloram-supplemented medium and when the lobes from young leaves were cultivated in medium containing 2,4-D.

Similar to the frequency of calli with embryos, the number of embryos per callus was not influenced by the type of explants. Nevertheless, a significant interaction between types and concentration of auxin in the number of embryos per callus was registered. The data showed that the picloram increased the number of embryos per callus independent of the concentration when compared to 2,4-D. In both evaluation periods (55 and 75 days), however, $8 \mathrm{mg} \mathrm{L}^{-1}$ of picloram provided higher number of embryos per callus (Table 1).

The visual assessment under stereomicroscopy revealed the asynchronous formation of somatic embryos

Figure 1 - Frequency (\%) of calluses that exhibited the development of cassava somatic embryos after 55 and 75 days of

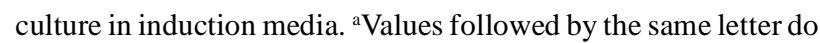
not differ significantly using the Tukey's test at 5\% significance

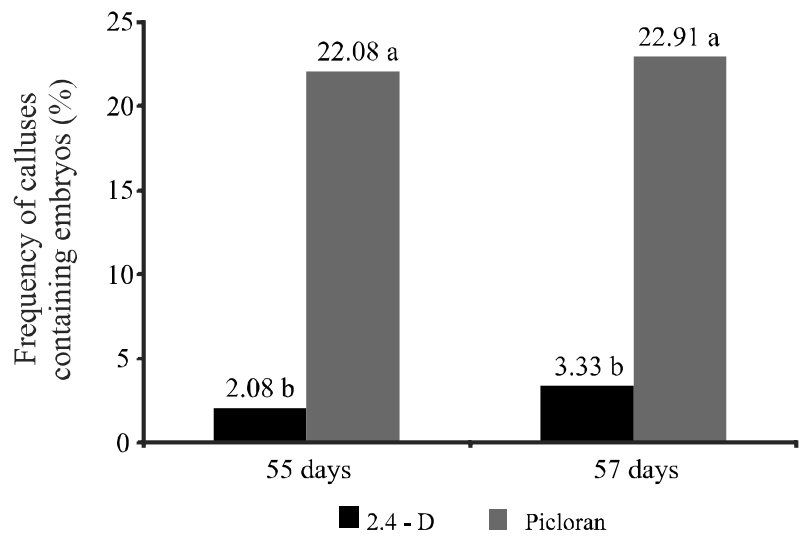


Table 1 - Average number of somatic embryos in calluses arising from cassava explants after 55 and 75 days of culture in induction media

\begin{tabular}{lcccc}
\hline \multirow{2}{*}{ Concentrations } & \multicolumn{3}{c}{55 days } & \multicolumn{2}{c}{75 days } \\
\cline { 2 - 5 } & $2,4 \mathrm{D}$ & Picloran & $2,4 \mathrm{D}$ & Picloran \\
\hline $8 \mathrm{mg} \mathrm{L}^{-1}$ & $0,05 \mathrm{aB}$ & $2,01 \mathrm{aA}$ & $0,07 \mathrm{aB}$ & $2,99 \mathrm{aA}$ \\
$12 \mathrm{mg} \mathrm{L}^{-1}$ & $0,08 \mathrm{aB}$ & $1,06 \mathrm{bA}$ & $0,18 \mathrm{aB}$ & $1,17 \mathrm{bA}$ \\
\hline
\end{tabular}

${ }^{a}$ The means followed by the same letter do not differ significantly using a Tukey's test at $5 \%$ significance

exhibiting globular, torpedo and cotyledonary stages in the same callus (Figure 2B). Independent of the assessed factors, the embryos in the torpedo stage were observed in the induction medium at both time points (days 55 and 75), whereas the largest number of embryos in the cotyledonary stage were observed only on day 75 . At that time (75 days), embryos in the globular stage were not observed, which is expected because the globular stage represents the initial stage of histodifferentiation.
In addition, embryos exhibiting fused cotyledons were observed, which is not desirable because these embryos do not develop normally. Following transfer to the development medium, a number of these embryos did indeed exhibit abnormal development, resulting in the altered morphology of the aerial part of the embryo in particular, which exhibited an indefinite foliar structure (Figure 2C) and did not progress into plants.

Figure 2 - Somatic embryogenesis and regeneration of cassava plants: A) foliar explant in induction medium supplemented with $8 \mathrm{mg} \mathrm{L}^{-1}$ of picloram exhibiting callus formation after 30 days of culture; B) somatic embryos at different stages in a single callus (a - globular, b - torpedo, c - cotyledonary) after 75 days in induction medium; C) abnormal embryos in development medium; D) plant formed in germination medium; E) fully developed plant in multiplication medium. Bars: A, C) 0,5 cm; B) $0,25 \mathrm{~cm}$; D, E) $1,0 \mathrm{~cm}$
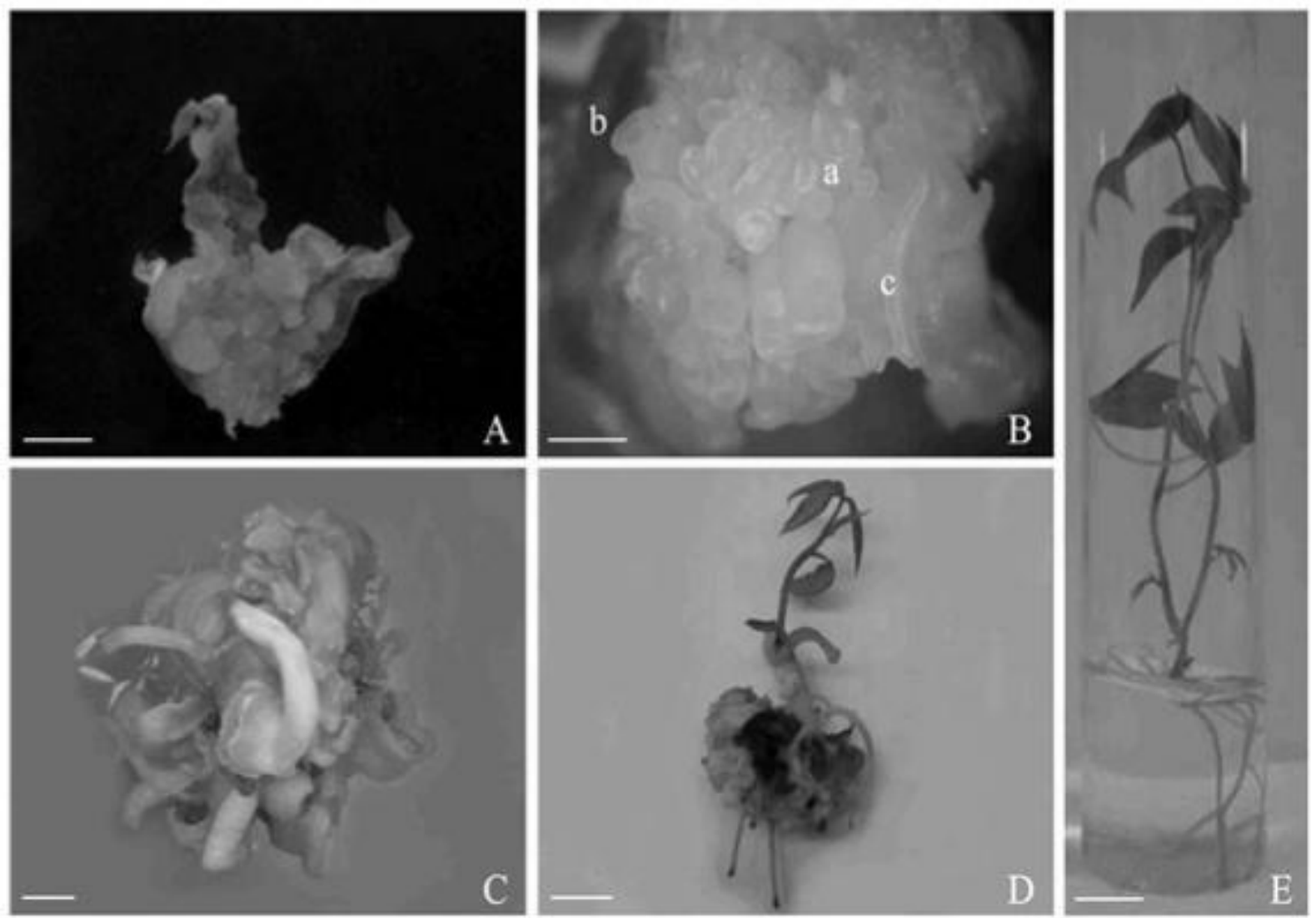
After induction, the somatic embryos derived from the picloram treatment were transferred to the D1 and D2 development media; however, because the number of embryos produced from the 2,4-D treatment was small, these embryos were transferred only to the D1 medium.

During culture in the D1 and D2 development media, the growth of the embryos was observed as early as the first week, especially in the aerial part of the embryo. However, the embryos produced from the foliar explants that were cultured in the presence of both concentrations of picloram and cultured in D2 medium developed faster and were transferred to the germination medium (two weeks) earlier. Conversely, independent of their origin, the embryos cultured in the D1 medium required approximately 10 weeks incubation before they could be transferred to the germination medium.

In the embryos derived from both the apex and leaf explants cultured with picloram, germination occurred only when the embryos were cultured in D2 medium. In this regard, the best results were observed with the embryos originating from foliar explants. As soon as the plantlets developed (Figure 2D), they were transferred to conventional cassava multiplication medium and exhibited normal and homogeneous development and rooted and elongated satisfactorily (Figure 2E).

In the embryos derived from the foliar explants inoculated in media containing 2,4-D at both concentrations and cultured in D1 medium, the histological sections demonstrated the re-differentiation of the cells with the conversion into pro-embryonary complexes at a later stage (Figure 4A). These cell complexes became globular, heart-shaped, torpedo, and cotyledonary structures, thus undergoing the same developmental stages as zygotic embryos (Figures 3A and 3B); however, these embryos did not develop into plantlets.

The absence and low rate of conversion of the somatic embryos into plantlets have hindered the application of this biotechnological technique to a number of crops, such as Acrocomia aculeata (MOURA et al., 2009) and Acca sellowiana (PESCADOR et al., 2008). Several morphologic abnormalities were determined as the main causes for the lack of or low conversion rates of the somatic embryos into plants in vitro, including mono- or multicotyledonary embryos, fused cotyledons, trumpet-shaped,

Figure 3 - Somatic embryos of cassava originating from immature leaves incubated in induction medium containing $8 \mathrm{mg} \mathrm{L}^{-1}$ of 2,4-D and later cultured in D1 medium. A) multiple somatic embryos in D1 medium at different developmental stages, globular (arrow), heart-shaped (arrowhead), and torpedo (t); B) embryo at the heart-shaped stage independent of the initial explant (arrow); C) cornet-type somatic embryos in development medium at the cotyledonary stage (arrow); D) pro-embryonary cell complex demonstrating multicellular origin (om) and initial formation of the globular structure (arrow); E) embryo at the torpedo stage with the initial formation of the procambium (arrowhead) and embryonary axis (arrow); F) embryo at the cotyledonary stage (co) exhibiting the root sub-apical meristem (mr) and lacking the shoot apical meristem (arrow). Bars: A, C) $0,1 \mathrm{~cm}$; B, D) $100 \mu \mathrm{m}$; E, F) $200 \mu \mathrm{m}$
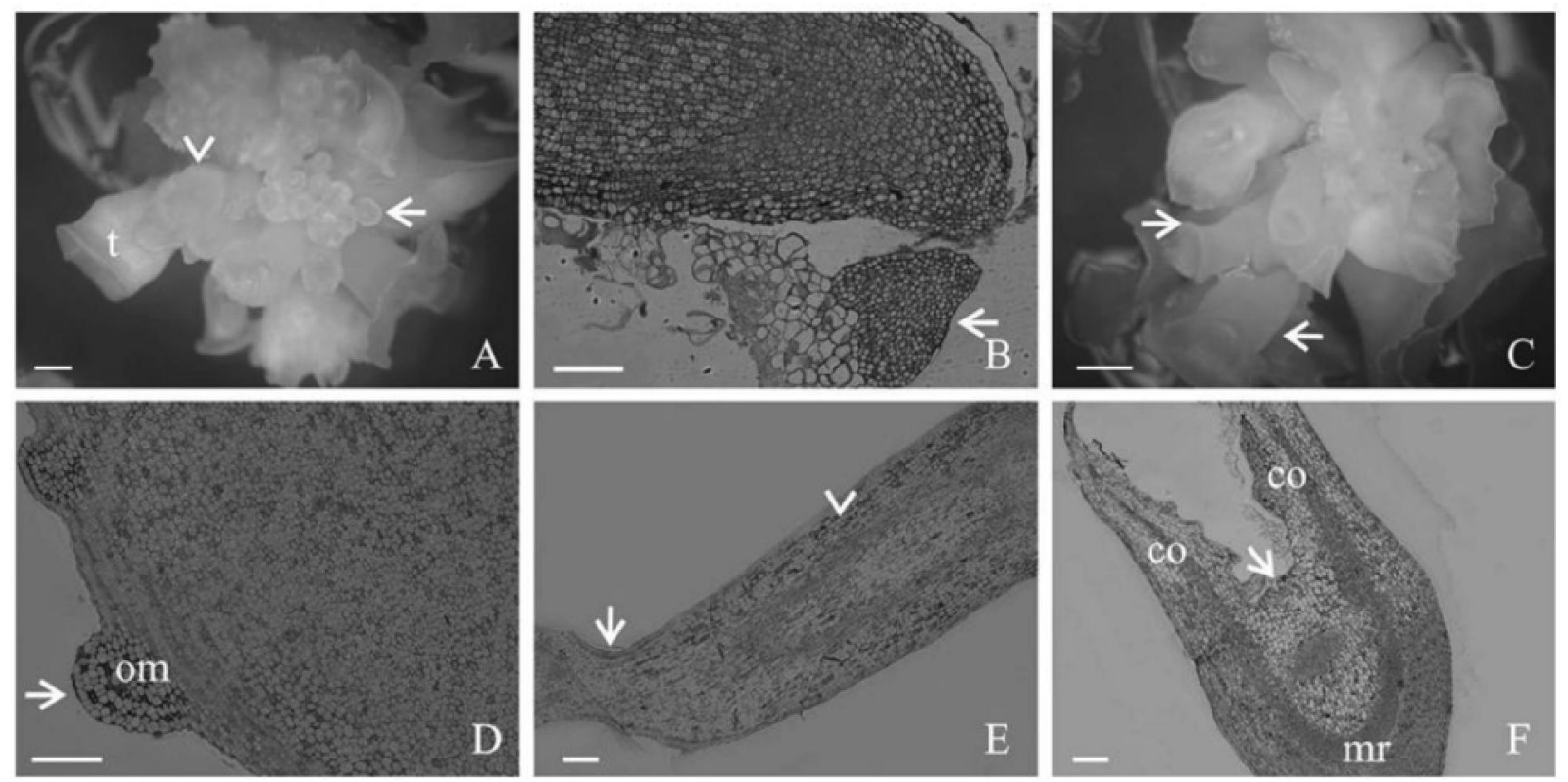
Figure 4 - Somatic embryos of cassava originating from immature leaves in induction medium containing $12 \mathrm{mg} \mathrm{L}^{-1}$ of 2,4-D and later cultured in D1 medium. A) pro-embryonary cell complex formed in the induction medium; B) cornet-shaped (arrow), multi-cotyledonary embryos (arrowhead) and embryos at the torpedo stage (t) in maturation medium demonstrating asynchronous development; C) proembryonary cell complex demonstrating multicellular origin (om), and initial formation of the globular structure (arrow) without full formation of the protoderm (pt); D) globular structure independent of the initial explant (arrow) with irregular protoderm (pt); E) embryo at the torpedo stage with formation of the root sub-apical meristem (mr) and demonstrating the embryonary axis at the basal area (arrow); F) abnormal multi-cotyledonary embryo (arrowhead). Bars: A, B) 0,1 cm; C) $50 \mu \mathrm{m}$; D, E, F) $200 \mu \mathrm{m}$
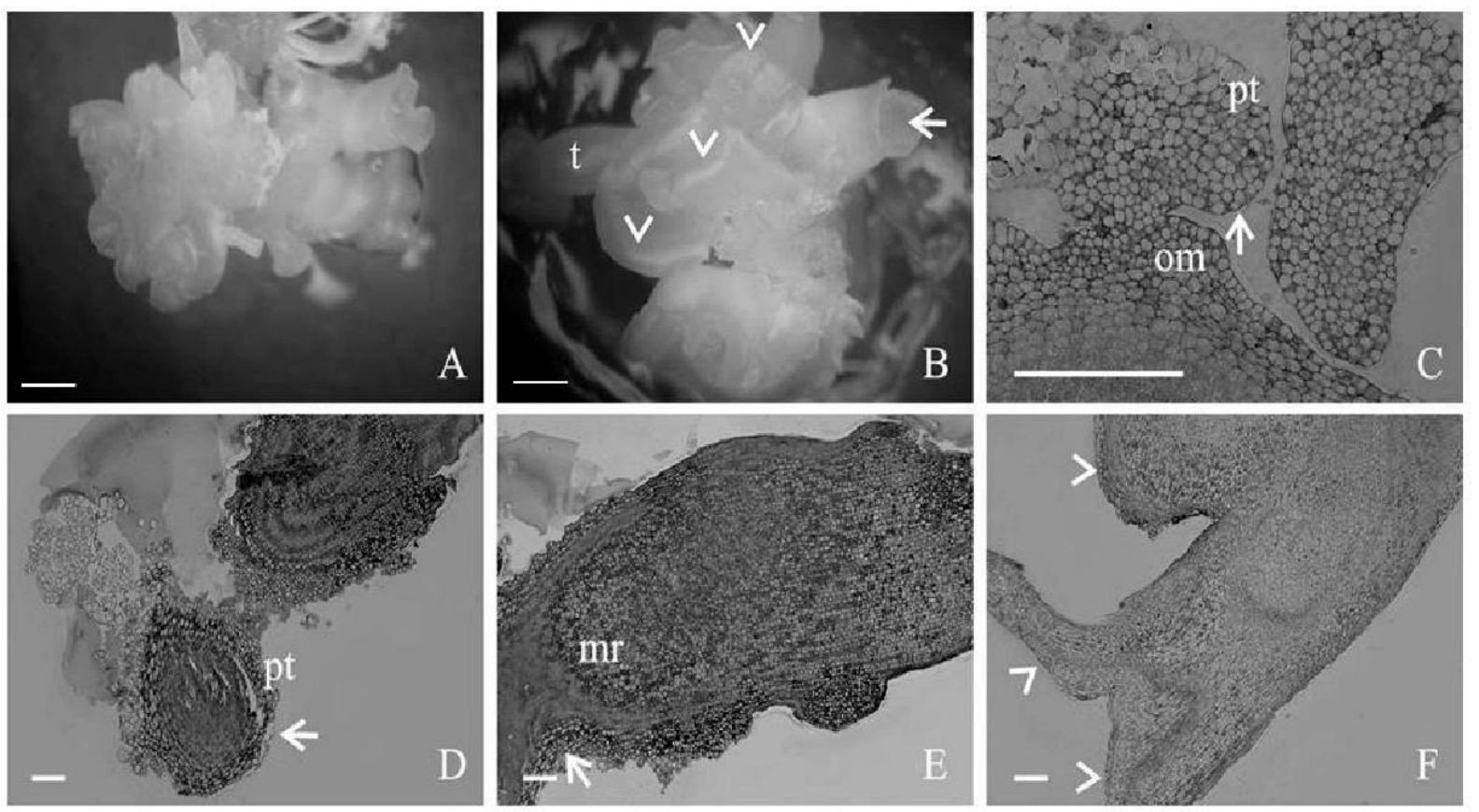

vestigial cotyledons, fasciated embryos, giant embryos, and cornet-shaped embryos (MENGARDA et al., 2009; RUSSAIN et al., 2009). This study demonstrated a remarkable number of embryos classified as cornet-shaped (Figure 3C) as well as multi-cotyledonary (Figure 4B), which might explain the low conversion rate observed.

Yeung (1995) determined that the formation of the protoderm is an important step in embryogenesis and signals the onset of the histodifferentiation of somatic embryos. The study also demonstrated that the interruption of the development of somatic carrot embryos was because of abnormal protoderm formation.

In this study, the histological sections from several structures point to the multicellular origin of the embryo structures and the onset of the globular stage, with complete (Figure 3D) and incomplete (Figure 4C) protoderm formation in induction medium containing 8.0 and $12 \mathrm{mg} . \mathrm{L}^{-1}$ of $2,4-\mathrm{D}$, respectively. The incomplete formation of the protoderm might affect the full development of the epidermis, stalks, and roots. In addition, the globular structure was independent of the initial explant cultured in induction medium containing $12.0 \mathrm{mg} \mathrm{L}^{-1}$ of 2,4-D; however, alterations in the protoderm (Figure 4D), characterized by several non-uniform cell layers, were observed. These alterations were not observed in structures originating from the culture medium containing $8.0 \mathrm{mg} \mathrm{L}^{-1}$ of 2,4D. According to Pescador et al. (2008), the anomalous embryos of Acca sellowiana resulted to a large extend from deleterious effects of 2,4-D on the normal genetic and/or physiological processes. Therefore, this concentration of 2,4-D may have contributed to the occurrence of the abnormality observed in this study. Liu, $\mathrm{Xu}$ and Chua (1993) determined that the polar transport of auxin in the initial stage of globular embryo development is crucial for the establishment of bilateral symmetry, which might be affected when the distribution of auxin is homogeneous across the entire embryo.

These irregularities may have contributed to the lack of full differentiation of the embryonary structure resulting in the non-conversion into plants. As mentioned above, the unicellular origin of somatic embryos was not observed, and none of the embryos 
exhibited a structure similar to the suspensor in any of the induction media used.

According to Dornelas, Vieira and Appezzato-daGlória (1992), the base of the embryonary axis of somatic embryos of multicellular origin tends to be widely linked to the explant, without the formation of the suspensor or an equivalent structure, and this phenomenon was also observed in this study (Figures 3E and 4E).

The cotyledonary stage was characterized by the formation of multi-cotyledonary embryos containing two cotyledons (Figure 3F), and only multi-cotyledonary embryos (Figure 4F) were obtained for the explants cultured in induction medium containing 8.0 and $12.0 \mathrm{mg} . \mathrm{L}^{-1}$ of 2,4-D. In both cases, cornet-shaped embryos were the morphologic type found most frequently in this study. This embryo type was observed in several other studies (MOURA et al., 2009) in which the absence of the shoot apical meristem was observed. Hartweck et al. (1988) reported that although cornet-shaped embryos might germinate, they are unable to become plantlets.

It is worth emphasizing that in this study, the process of somatic embryogenesis occurred asynchronously because globular somatic embryos were observed together with embryos at more advanced stages of development (Figure 4B).

It is also worth noting that in this study, the malformations observed during the in vivo embryogenic process might be related to the addition of auxin to the culture medium and the long culture period. Therefore, studies that produce embryos of superior quality that can undergo conversion into plantlets are needed. The quality of the somatic embryos together with the source and concentration of auxins, the time of induction, and the stage of maturation are necessary and crucial requirements for efficient somatic embryogenesis.

\section{CONCLUSIONS}

1. The highest frequency of calluses and the greatest number of embryos per callus was obtained using $8.0 \mathrm{mg} \mathrm{L}^{-1}$ of the auxin picloram;

2. The shoot apical meristem did not form in the embryos originating from the culture media containing 2,4-D, and the majority of the embryos were classified as cornet-shaped;

3. The cotyledonary structures originate independently of the formation of the shoot apical meristem.

\section{ACKNOWLEDGMENTS}

We acknowledge the Bahia Research Support Foundation (Fundação de Amparo à Pesquisa do Estado da Bahia - FAPESB) for the scholarship. To Dr. Adriana Pinheiro Martinelli and Mônica Lanzoni Rossi for her important contributions to the preparation of samples and the acquisition of the microscopy images.

\section{REFERENCES}

ALVES, A. et al. Alterações na qualidade de raízes de mandioca (Manihot esculenta Crantz) minimamente processadas. Ciência e Agrotecnologia, v. 29, n. 2, p. 330337, 2005.

ATEHNKENG, J.; ADETIMIRIN, V. O.; NG, S. Y. C. Exploring the African cassava (Manihot esculenta Crantz) germplasm for somatic embryogenic competence. African Journal of Biotechnology, v. 5, n. 14, p. 1324-1329, 2006.

CANHOTO, J. M.; RAMA, S. C.; CRUZ, G. S. Somatic embryogenesis and plant regeneration in carob (Ceratonia siliqua L.). In Vitro Cellular \& Developmental Biology Plant, v. 42, n. 6, p. 514-519, 2006.

CENTRO INTERNACIONAL DE AGRICULTURA TROPICAL. El cultivo de meristemas para saneamento de clones de yuca. Guía de estúdio. Calí, Colombia, 1982. 45 p. (Serie 04SC-02.05.).

DORNELAS, M. C.; VIEIRA, M. L. V.; APPEZZATO-DAGLORIA, B. Histological analysis of organogenesis and somatic embryogenesis induced in immature tissues of Stylosanthes scabra. Annals of Botany, v. 70, n. 5, p. 477-482, 1992.

FEDER, N.; O'BRIEN, T. P. Plant microtechnique: some principles and new methods. American Journal of Botany, v. 55, n. 1, p. 123-142, 1968.

HANKOUA, B. B. et al. Production of the first transgenic cassava in Africa via direct shoot organogenesis from friable embryogenic calli and germination of maturing somatic embryos. African Journal of Biotechnology, v. 5, n. 19, p. 1700-1712, 2006.

HARTWECK, L. M. et al. Auxin-orientation effects on somatic embryogenesis from immature soybean cotyledon. In Vitro Cellular \& Developmental Biology, v. 24, n. 8, p. 821-828, 1988.

IBARAKI, Y:; MURATA, K. Automation of somatic embryo production. Plant Cell, Tissue and Organ Culture, v. 65, n. 3, p. 179-199, 2001.

IBRAHIM,A. B. et al. Optimization of somatic embryogenesis and selection regimes for particle bombardment of friable embryogenic callus and somatic cotyledons of cassava (Manihot esculenta Crantz). African Journal of Biotechnology, v. 7, n. 16, p. 2790-2797, 2008.

IBRAHIM, A. B. et al. Development of Transgenic Cassava Cultivars from Northeastern Brazil. In: INTERNATIONAL MEETING ON CASSAVA BREEDING, BIOTECHNOLOGY AND ECOLOGY, 1., 2006, Universidade de Brasília. Proceedings... Brasília, 2006. 
JOSEPH, R.; YEOH, H. H.; LOH, C. S. Induced mutations in cassava using somatic embryos and the identification of mutant plants with altered starch yield and composition. Plant Cell Reports, v. 23, n. 1/2, p. 91-98, 2004.

LI, R. M. et al. $\mathrm{CaCl} 2$ Enhanced Somatic Embryogenesis in Manihot esculenta Crantz. Bioscience, Biotechnology and Biochemistry, v. 73, n. 11, p. 2513-2515, 2009.

LI, H. Q, et al. Regeneration of cassava plants via shoot organogenesis. Plant Cell Reports, v.17, p. 410-414, 1998.

LIU, C.; XU, Z.; CHUA, N. H. Auxin polar transport is essential for the establishment of bilateral symmetry during early plant embryogenesis. Plant Cell, v. 5, n. 6, p. 621-630, 1993.

MAGALHÃES, J. S. et al. Indução de embriogênese somática em genótipos de batata-doce. Horticultura Brasileira, v. 24, n. 1, p. 79-83, 2006.

MENGARDA, L. H. G. Efeito do frio sobre os carboidratos solúveis em culturas embriogênicas de Acca sellowiana O. Berg (Myrtaceae). Revista Brasileira Botânica, v. 32, n. 2, p. 307-317, 2009.

MOURA, E. F. et al. Somatic embryogenesis in macaw palm (Acrocomia aculeata) from zygotic embryos. Scientia Horticulturae, v. 119, n. 4, p. 447-454, 2009.

MURASHIGE, T.; SKOOG, F. A revised medium for rapid growth and bio assays with tobacco tissue cultures. Physiologia Plantarum, v. 15, n. 3, p. 473-497, 1962.

PESCADOR, R. et al. Anomalous somatic embryos in Acca sellowiana (O. Berg) Burret (Myrtaceae). Revista Brasileira Botânica, v. 31, n. 1, p.155-164, 2008.

PINHEIRO, M. V. M. et al. Maturation of Anthurium andraeanum cv. Eidibel somatic embryos from nodal segments. In Vitro Cellular Developmental Biology-Plant, v. 49, n. 3 , p. $304-312,2013$.

RODRIGUEZ, A. P. M.; WETZSTEIN, H. Y. A morphological and histological comparison of the initiation and development of pecan (Carya illinoinensis) somatic ambryogenic cultures induced naphthaleneacetic acid or 2,4-D acid. Protoplasma, v. 204 , n. $1 / 2$, p. $71-83,1998$.

SILVA, M. A. da et al. Variação nos teores de compostos cianogênicos durante o processo de fenação de ramas de mandioca ( Manihot esculenta Crantz). Magistra, v. 23, n. 3, p. 149-153, 2011.

ROSSIN, C. B.; REY, M. E. C. Effect of explant source and auxins on somatic embryogenesis of selected cassava (Manihot esculenta Crantz) cultivars. South African Journal of Botany, v. 77, n. 1, p. 59-65, 2011.

RUSSAIN, S. S. et al. Cotton somatic embryo morphology affects its conversion to plant. Biologia Plantarum, v. 53, n. 2, p. 307-311, 2009.

SZABADOS, L.; HOYOS, R.; ROCA, W. In vitro somatic embryogenisis and plant regeneration of cassava. Plant Cell Reports, v. 6, n. 3, p. 248-251, 1987.

TAKAMI, K. et al. Production of intergeneric somatic hybrids between round kumquat (Fortunella japonica Swingle) and 'Morita navel' orange (Citrus sinensis Osbeck). Plant Cell Reports, v. 23, n. 1/2, p. 39-45, 2004.

TAYLOR, N. et al. Development and application of transgenic technologies in cassava. Plant Molecular Biology, v. 56, n. 4, p. 671-688, 2004.

UZELAC, B. et al. Origin and development of secondary somatic embryos in transformed embryogenic cultures of Medicago sativa. Biologia Plantarum, v. 51, n. 1, p. 1-6, 2007.

YEUNG, E. C. Structural and developmental patterns in somatic embryogenesis. Plant Science and Biotechnology in Agricultura, v. 20, p. 205-247, 1995.

ZHANG, P. et al. Production of stably transformed cassava plants via particle bombardment. Plant Cell Reports, v. 19, n. 10, p. 939-945, 2000. 